\title{
PENGURANGAN BIAYA PENYIMPANAN (CARRYING COST) LIMBAH \\ DENGAN CARA PEMANFAATAN LIMBAH AMPAS EKSTRAK JAMU MENJADI PUPUK ORGANIK
}

\author{
Rimsa Rusmiland ${ }^{1)}$, Muhammad Fidiandri Putra ${ }^{2)}$ \\ ${ }^{1,2}$ Program Studi Teknik Industri, FT-MIPA \\ Universitas Indraprasta PGRI \\ rrfj60@gmail.com \\ fidiandri.putra@gmail.com
}

\begin{abstract}
The main purpose of the research of utilization of herbal extract waste into organic fertilizer is to reduce the storage cost of waste products that accumulated without being utilized. Because scientific research has not been done especially in PT Mustika Ratu Tbk., the waste of herbal extracts waste is only thrown away, and only 10\% for internal needs. The results of dregs about $300 \mathrm{~kg} /$ day, then this study wanted to prove whether the processed dregs of herbs can fertilize the soil or not. The second goal is that this waste can be converted into added value for the company that is the coaching program, the training of how to make fertilizer in the hope that can be utilized by the people surround PT Mustika Ratu like Ciracas, Cibubur and Cipayung and the east Jakarta Government Park. The long-term goal is how company and the society are interested to utilize waste extract of herbal medicine into high economic value and reduce the impact of waste on society and the environment.
\end{abstract}

Keyword: herbal extracts waste, inventory cost, empowerment

\begin{abstract}
ABSTRAK
Tujuan utama dari penelitian pemanfaatan limbah ekstrak jamu menjadi pupuk organik adalah mengurangi biaya penyimpanan produk limbah yang terakumulasi tanpa dimanfaatkan. Oleh karena belum dilakukan penelitian secara ilmiah terutama di PT. Mustika Ratu, limbah ampas ekstrak jamu hanya dibuang percuma, dan hanya 10\% untuk kebutuhan internal. Dari hasil ampas sekitar 300 $\mathrm{kg} / \mathrm{hari}$, peneliti ingin membuktikan dengan proses pengolahan lebih lanjut ampas jamu dapat menyuburkan tanah atau tidak. Tujuan kedua adalah limbah ini diharapkan bisa diubah menjadi suatu yang mempunyai nilai tambah bagi perusahaan, yaitu sebagai program pembinaan ,pembekalan, pelatihan pembuatan pupuk, dengan harapan bisa dimanfaatkan masyarakat sekitar Ciracas, Cibubur dan Cipayung serta taman pemerintah DKI Jakarta timur. Adapun tujuan jangka panjangnya adalah bagaimana pengusaha dan masyarakat tertarik untuk memanfaatkan limbah ampas ekstrak jamu menjadi nilai ekonomis yang tinggi serta mengurangi dampak limbah terhadap masyarakat dan lingkungan
\end{abstract}

Kata Kunci : Ampas ekstrak jamu, biaya penyimpanan, pemberdayaan 


\section{PENDAHULUAN}

PT. Mustika Ratu, Tbk merupakan produsen pembuatan produk jamu tradisional di Indonesia yang telah berdiri sejak 1981. Salah satu produk yang dihasilkan adalah teh celup yang diproses melalui ekstraksi dengan menggunakan material rempah-rempah, seperti jahe, temu kunci, kencur, jati belanda, tempuyung, kunyit, pulo sari, kayu manis, temu ireng, bangle, temu lawak, kedaung, ADAS dan lempuyang wangi. Setelah proses ekstraksi, akan timbul ampas ekstrak atau limbah ekstrak dan harus dibuang. Jumlah limbah ampas ekstrak jamu dari proses ekstraksi tersebut sebanyak $300 \mathrm{~kg} /$ hari. Saat ini, limbah tersebut belum termanfaatkan secara maksimal. Volume limbah ini menimbulkan permasalahan bagi lingkungan.

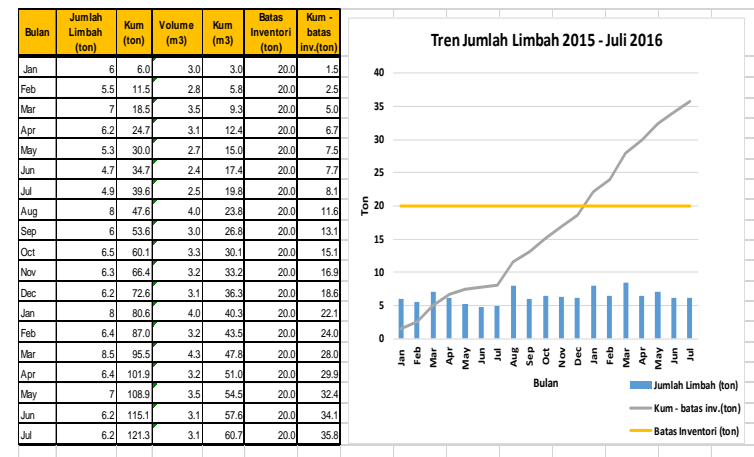

Gambar 1. Grafik Limbah dari ampas rempah tahun 2015 -Juli 2016

Dari Gambar 1 di atas terlihat limbah ampas adalah masalah yang serius bagi PT. Mustika Ratu, yang mana ruang penyimpanan untuk limbah yang tersedian yaitu untuk 20 ton, mulai tidak mencukupi dengan laju penambahan limbah jamu tersebut. Biaya yang ditimbulkan selain biaya penyimpanan (Carrying Cost), juga ada biaya untuk pembuangan limbah ke pihak ketiga.Hal ini terpaksa dilakukan jika ruang tempat penyimpanan sudah tidak dapat menampung limbah tersebut. Isu lain yang tidak boleh diabaikan adalah isu lingkungan dimana limbah ini juga akan meinmbulkan bau yang tidak sedap yang dapat mengganggu pemukiman disekitar pabrik PT. Mustika Ratu.

\section{Metode}

Metode penelitian ini adalah menggunakan metode eksperimen dengan membuat percobaan pembuatan pupuk dari ampas jamu yang bahannya terdiri dari sisa atau ampas jahe, temu kunci, kencur, jati belanda, tempuyung, kunyit, pulo sari, kayu manis, temu ireng, bangle, temu lawak, kedaung, ADAS dan lempuyang wangi dengan dilakukan proses tambahan dengan EM 4 dan Gula Pasir.

Jika dari percobaan pembuatan pupuk ini berhasil memenuhi kandungan makro nutrient (N,P.K) sebagai pupuk organik maka tentunya dapat dilakukan proses pengolahan atau produksi secara massal guna dijadikan pupuk yang dapat dimanfaatkan untuk kebutuhunan pupuk bagi warga sekitar. Oleh karena metoda pengolahannya yang sederhana, produksi dengan skala besar dapat dilakukan oleh perusahaan atau penduduk yang ingin memanfaatkan limbas ampas ini.

Inti atau kunci dari proses pembuatan pupuk ini yaitu bagaimana kandungan makro nutrient $(\mathrm{N}, \mathrm{P}, \mathrm{K})$ pupuk organik dari limbah ekstrak jamu dengan activator dari EM 4.

Kegiatan penelitian dilakukan di PT. Mustika Ratu, Tbk (Jakarta) dan Laboratorium SEAMEO BIOTROP di Bogor, sebagai lembaga yang meneliti hasil dari proses pengolahan ampas jamu menjadi pupuk apakah memenuhi persyaratan sebagai pupuk organik.

Bahan penelitian berupa limbah ampas ekstrak jamu dari proses ekstraksi sebanyak 1 ton, 1 botol larutan EM 4 kemasan 1 liter untuk mempercepat proses pembuatan pupuk organik sebagai aktivator dan gula pasir 1 sendok.

Peralatan yang digunakan antara lain karung plastik, mesin pengering bekas ekstraksi buah, $\mathrm{pH}$ meter, thermometer, cangkul, sarung tangan, timbangan dan kantong plastik.

\section{Prosedur Kerja}

Prosedur kerja pembuatan pupuk organic dari limbah ekstrak jamu sebagai berikut :

- Limbah ampas ekstrak jamu dimasukkan kedalam mesin pengering kemudian dilakukan pencucian untuk menghilangkan kandungan alcohol selama 15 menit sampai bersih.

- Setelah bersih, ditimbang sebanyak $50 \mathrm{~kg}$ dan ditaruh didalam karung.

- Kemudian activator disiapkan dengan menyiapkan air 1 liter di gelas ukur, masukkan larutan EM 4 sebanyak $10 \mathrm{ml}$ dan ditambahkan gula pasir 1 sendok makan sebagai pengganti molase diaduk rata. 
- Selanjutnya activator disiramkan ke dalam karung lalu diaduk rata kembali.

- Pengadukan dilakukan satu minggu satu kali sampai dengan 3 minggu.

- Setiap 1 minggu sekali dilakukan pengecekan suhu, $\mathrm{pH}$ dan kelembaban sampai proses berakhir.

- Sesudah proses pembuatan pupuk organic, dilakukan analisis kadar air, unsur hara makro, nisbah $\mathrm{C} / \mathrm{N}$ serta kandungan logam berat. Analisa dilakukan di Laboratorium Tanah, BIOTROP, Bogor.

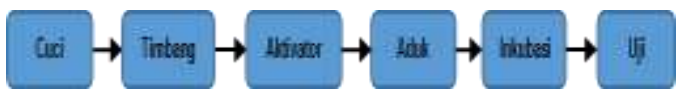

Gambar 2. Urutan Proses Pembuatan Pupuk

\section{Eksperimen dan Hipotesis Hasil Uji}

Peneliti telah mencoba menguji sampel limbah ampas ekstrak jamu ke Laboratorium BBIA Agro dengan hasilnya sebagai berikut :

\begin{tabular}{|c|c|c|c|}
\hline Parameter & Satuan & Hasil & Metode Uji \\
\hline Air & $\%$ & 0,81 & SN1 01-2891-1992 butir 5.1 \\
\hline Abu & $\%$ & 6,62 & SN1 01-2891-1992 butir 6.1 \\
\hline Protein & $\%$ & 8,09 & SNI 01-2891-1992 butir 7.1 \\
\hline Lemak & $\%$ & 2,55 & SN1 01-2891-1992 butir 8.1 \\
\hline Karbohidrat & $\%$ & 81,9 & Pengurangan \\
\hline
\end{tabular}

Gambar 3. Hasil Uji Laboratorium BBIA Agro

Dari gambar 3 diatas menunjukkan kadar Karbohidrat sangat tinggi sebanyak $81,9 \%$, yang artinya limbah ampas jamu masih bisa dimanfaatkan untuk keseburuan tanah dalam pembuatan pupuk organik dan juga bisa digunakan untuk pakan ternak lele.

Peneliti sudah melakukan percobaan untuk pembuatan pupuk organik dari ampas ekstak jamu dengan pencucian terlebih dahulu lalu penambahan mikrobacter EM 4 dan penambahan gula untuk proses pembusukan selama 3 minggu. Selanjutnya pupuk di ujicoba diberikan ke tanaman hias, tanaman buah dan tanaman tradisional. Hasilnya secara fisik terlihat tanaman subur dan kemudian pemanfaatan pupuk ini telah diberikan kepada karyawan, tamu dan warga sekitar lokasi pabrik. Limbah ekstrak jamu ini mendapat respon positif dari masyarakat sekitar ciracas dan cibubur.

Namun permasalahannya adalah belum diteliti secara ilmiah kandungan dari pupuk organik ini dari unsur $\mathrm{P}, \mathrm{N}$, dan $\mathrm{K}$ nya.
Penelitian sebelumnya hanya meneliti ampas kunyit untuk diambil kandungan oleoresin.

\section{Hasil dan Pembahasan}

Setelah dilakukan pengomposan selama 3 (tiga) minggu kemudian sampel pupuk ampas jamu seberat 5 (lima) $\mathrm{kg}$ di kirim ke Laboratorium yang terakreditasi oleh KAN No. LP-221-IDN yaitu Seameo Biotrop pada tanggal 11 November 2016. Tanggal pelaksanaan analisis pada 20 November 2016 s/d 11 Januari 2017, proses pengujian dilakukan selama 2 (dua) bulan dan selesai pada tanggal 12 Januari 2017. Berikut ini adalah hasil pengujiannya :

\begin{tabular}{|c|c|c|c|c|c|}
\hline $\mathrm{pH}$ & COrg & N Total & Rasio & P205 Total & K20 Total \\
\hline \multirow[t]{2}{*}{$(1: 2,5)$} & Walkey \& & \multirow{2}{*}{ Kjeldahl } & $\mathrm{C} / \mathrm{N}$ & Spektrofotometri & Flame Emisi \\
\hline & Black & & & (HNO3-HCLO4) & (HNO3-HClO4) \\
\hline \begin{tabular}{l|l|}
$\mathrm{H} 2 \mathrm{O}$ & $\mathrm{KCl}$ \\
\end{tabular} & $\%$ & $\%$ & . & $\%$ & $\%$ \\
\hline 8 & 29.33 & 4.13 & 7 & 8.55 & 12.32 \\
\hline
\end{tabular}

Gambar 4. Hasil Uji di Seameo Biotrop tanggal 20 November 2016 - 11 Januari 2017

Berdasarkan lampiran I.1 Peraturan Menteri Pertanian No. 70 Tahun 2011 mengenai persyaratan teknis minimal pupuk organik padat, yaitu :

\begin{tabular}{|c|l|c|c|}
\hline No. & \multicolumn{1}{|c|}{ Parameter } & Satuan & $\begin{array}{c}\text { Standar } \\
\text { Kualitas }\end{array}$ \\
\hline 1 & C-organik & $\%$ & Min. 15 \\
\hline 2 & Kadar Air (H2O) & $\%$ & $8-10$ \\
\hline 3 & Hara makro (N + P2O5 + K2O) & $\%$ & 4 \\
\hline
\end{tabular}

Gambar 4. Persyaratan Teknis Minimal pupuk Organik

Menunjukkan kecenderungan kualitas yang baik dinilai dari hasil uji pada tabel diatas, nilai C-organik sebesar $29,33 \%$ dari yang disyaratkan sebesar min. $15 \%$, kemudian nilai kadar air (H2O) sebesar 8\% dari yang disyaratkan $8-20 \%$, terakhir nilai unsur hara makro untuk $\mathrm{N}$ sebesar 4,13\%, P 8,55\% dan $\mathrm{K}$ $12,32 \%$ dari yang disyaratkan min. $4 \%$.

Zat $\mathrm{N}$ atau zat lemasnya harus terdapat dalam bentuk persenyawaan organik, jadi harus mengalami peruraian menjadi persenyawaan $\mathrm{N}$ yang mudah dapat diserap oleh tanaman. Pupuk tersebut dapat dikatakan tidak meninggalkan sisa asam organik di dalam tanah. Pupuk ampas jamu mempunyai kadar persenyawaan $\mathrm{C}$ organik yang tinggi, seperti hidrat arang.

Percobaan yang dilakukan dimana 1 liter EM 4 dicampurkan ke dalam 1 ton ampas jamu, maka menghasilkan pupuk yang memenuhi 
persyaratan sebagai pupuk sehingga dapat efektif dan optimal dalam penggunaanya. Hasil uji menunjukkan bahwa bahan ampas jamu yang dicampur dengan EM4 dengan komposisi yang sudah ditentukan di atas memenuhi syarat sebagai kompos atau pupuk.

Contoh kompos hasil percobaan ini kemudian kami kirim kepada masyarakat 1 Rukun Warga guna dimanfaatkan sebagai pupuk, yang dimulai dari November 2016 hingga saat ini. (Grafik terlampir).

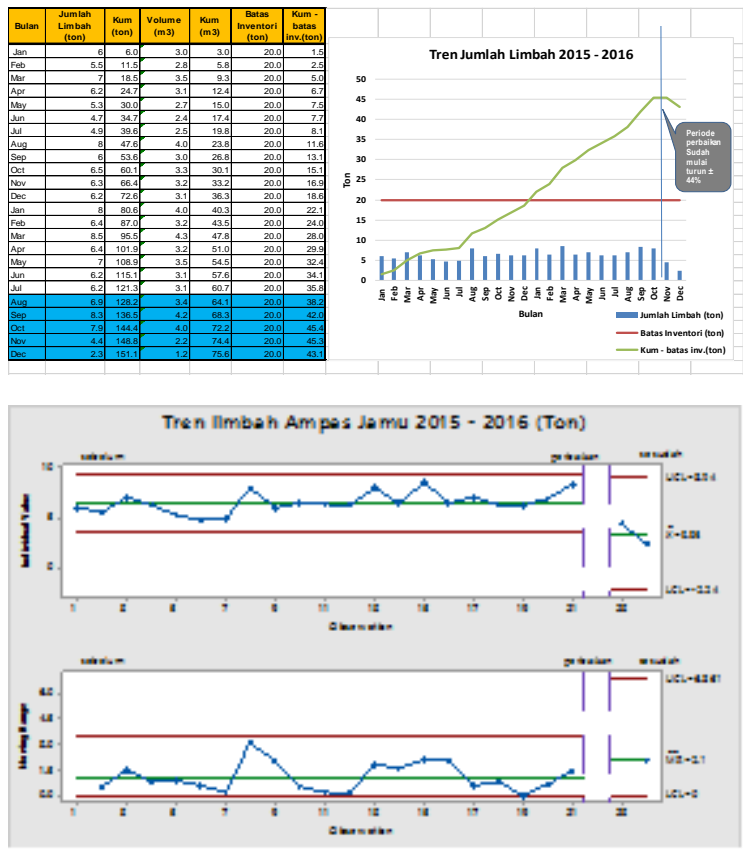

Gambar 5. Tren dan Akumulasi Jumlah Limbah

Dampak dari hasil pengolahan ampas jamu ini selama 3 bulan, dengan jumlah yang cukup besar sekitar 2 ton sangat terasa pengurangan biaya yang harus dikeluarkan oleh perusahaan untuk biaya pengiriman dan biaya penyimpanan. Biaya yang dapat dikurangi dari bulan Oktober hingga bulan Desember 2016 sebesar Rp. 40,530,000 (Ini adalah komulatif biaya dari biaya simpan dan biaya jasa pembuangan limbah).

\begin{tabular}{|l|r|r|r|r|}
\hline \multicolumn{1}{|c|}{ Rincian } & Oktober 2016 & November 2016 & Desember 2016 & SUB TOTAL (Rp.) \\
\hline Biaya Penvimpanan & & & & \\
\hline Upah Buruh (1 orang) & $2,800,000$ & $2,800,000$ & $2,800,000$ & \\
\hline Listrik & 250,000 & 250,000 & 250,000 & \\
\hline Alat dan transportasi internal (forklift, Karung) & 150,000 & 150,000 & 150,000 & \\
\hline & 100,000 & 100,000 & 100,000 & \\
\hline Total Biaya Penyimpanan & $3,300,000$ & $3,300,000$ & $3,300,000$ & $9,900,000$ \\
\hline & & & & \\
\hline Total Biaya Pembuangan ke PPLi & \multicolumn{1}{|c|}{7,91 Ton } & 8.45 Ton & \multicolumn{1}{|c|}{4.06 Ton } & \\
\hline (1 ton = Rp. 1,500,000) & $-11,865,000$ & $-12,675,000$ & $-6,090,000$ & $30,630,000$ \\
\hline
\end{tabular}

Gambar 6. Biaya yang dikeluarkan Perusahaan untuk Limbah Oktober - Desember 2016

\section{SIMPULAN DAN SARAN}

Merujuk pada tulisan Alyssa Nahla Amir dan Puspita Firsty Lestari, pada jurnal "Pengambilan Oleoresin Limbah Ampas Jahe Industri Jamu (PT Sido Muncul) dengan Metode Ekstraksi", limbah Ampas Jamu adalah bahan organik yang pada prinsipnya dapat diolah pada senyawa kimia tertentu dan proses tertentu, sehingga menghasilkan suatu bahan lain yang mempunyai manfaat atau tujuan hasil produk yan kita inginkan, seperti pupuk ataupun oleoserin pada penelitian ampas jamu jahe pada PT. Sido Muncul.

Limbah jamu yang dihasilkan oleh PT Mustika Ratu, Tbk.dapat dimanfaatkan sebagai pupuk organic setelah mengalami proses lebih lanjut dan dengan menambahkan EM4 dengan perbandingan tertentu, yang melalui proses inkubasi.

Dari hasil inkubasi tersebut, dihasilkan pupuk yang mempunyai unsur sebagai persyaratan menjadi pupuk yang memadai (kadar N, P, K melebihi persyaratan teknis minimal pupuk organik dalam peraturan menteri pertanian nomor.70 tahun 2011 ).

Dengan adanya pemanfaatan ampas jamu ini maka PT Mustika Ratu telah melakukan penghematan biaya penyimpanan (carrying cost) Rp. 3,300,000/bulan dan biaya dari pembuangan limbah ke PPLi sebesar Rp. $1.500 .000 / \mathrm{m} 2$.yang dari data di atas diperoleh biaya yang bisa dihemat dalam kurun waktu tiga bulan (November - Desember 2016) sebesar Rp.40,530,000,-

Dengan adanya penelitian ini secara skala besar, diharapkan dapat dilanjutkan berupa bimbingan teknis cara pembuatan pupuk dari ampas jamu kepada masyarakat luas dan terutama masyarakat dilingkungan pabrik PT. Mustika Ratu.

\section{DAFTAR PUSTAKA}

Amir, AN \& Lestari, PF, Pengambilan Oleoresin Limbah Ampas Jahe Industri Jamu(PT Sido Muncul) dengan Metode Ekstraksi, Jurnal Teknologi Kimia dan Industri, Vol. 2, No.3, Tahun 2013, Hal 88-95

Rosmarkam, A, Yuwono, NW.(2002). Ilmu kesuburan tanah. Penerbit Kanisius: Yogyakarta 
Sudrajat, dkk, (2007). Pemupukan tanaman padi, Badan Litbang Pertanian Deptan.

Damanhuri, Enri, Padmi, T. (2006). Diktat kuliah TI-3150 Pengelolaan Sampah, Edisi Semester I 2006/2007,Program Studi Teknik Lingkungan, ITB

Robert, FJ, Richard B.C.(2011).Operation and Supply Chain Management, $14^{\text {th }}$. GlobalEdition,Mc Graw Hill, New York USA

Heizer, Jay and Barry Bender.(2001).Operation Management, $6^{\text {th }}$ edition,Prentice-Hall.Inc, New Jersey

Musnamar, E. I.M.(2005). Pupuk Organik Padat: Pembuatan dan Aplikasi,Penebar Swadaya. Jakarta

Mulyadi.(1999).Akuntansi Biaya, Edisi lima, Aditya Media, Jogyakarta

Mulyono S.(2004).Riset Operasi, Edisi pertama, Penerbit BPFE, Jogyakarta

Murbandono, L.(2000). Membuat Kompos, edisi revisi, Penebar Swadaya, Jakarta

Said, N.I.(2011). Pengelolaan Limbah Domestik, BPPT, Jakarta

R.A. Supriyono.(1994). Akuntansi Biaya: Pengumpulan Biaya dan Penentuan Harga Pokok, Buku I, Edisi ke-2,BPFEUGM, Yogyakarta

Suharto, Ign.(2011).Limbah kimia dalam pencemaran udara dan air, penerbit Andi:Yogyakarta

Sutedjo.(2002).Pupuk dan cara penggunaan, Rineka Cipta, Jakarta

Yuwono,D. (2006). Kompos, Penebar Swadaya, Jakarta

Litbang Deptan.(2006).Pupuk Organik dan Pupuk Hayati Organik Fertilizer and Biofertilizer

http://balittanah.litbang.deptan.go.id/dokumenta si/juknis/pupuk\%20organik.pdf. diakses pada tanggal 10 september 2016. 